\title{
Serum and tissue autoantibodies to colonic epithelium in ulcerative colitis
}

\author{
J A Snook, J R Lowes, K C Wu, J D Priddle, D P Jewell
}

Gastroenterology

Department, Radcliffe

Infirmary, Oxford

J A Snook

J R Lowes

KCWu

J D Priddle

D P Jewell

Correspondence to:

Dr J A Snook, Royal Hants

County Hospital, Winchester,

Hampshire SO22 5DG.

Accepted for publication

27 March 1990
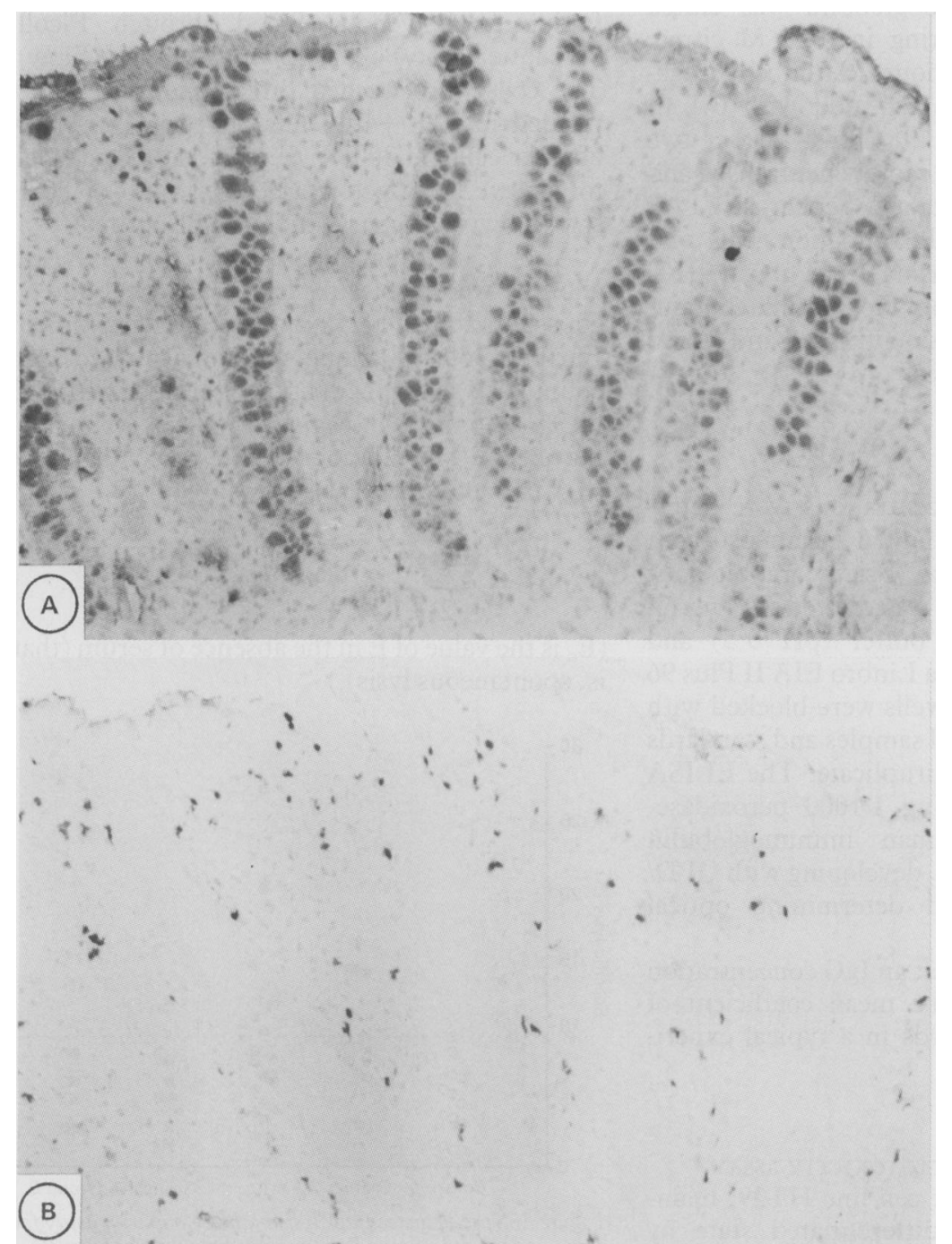

Figure 1: Immunoperoxidase demonstration of 'classical' anticolon antibody: $(A)$ positive serum, $(B)$ negative serum. Original magnification $\times 40$.

\begin{abstract}
Sera and colonic tissue-bound immunoglobulin extracts from patients with ulcerative colitis and disease controls were examined immunohistochemically and by killer cell cytotoxicity assay for the presence of anticolonic epithelial autoantibodies. IgG yields in the tissue extracts from patients with colitis and control subjects were similar, and the extracts were uniformly autoantibody negative. Of 41 sera from patients with inflammatory bowel disease, 'classical' anticolon antibody was present in $41 \%$ and was commoner in patients with sclerosing cholangitis. Cytotoxic anticolon antibody was present in $20 \%$ overall and was strongly associated with disease activity; it did not correlate with the presence of 'classical' anticolon antibody. The heterogeneous and non-universal antiepithelial auto-
\end{abstract} misease will clearly provide more direct information on which to base an assessment of the pathogenetic importance of autoantibody to colonic epithelium because the peripheral blood does not necessarily reliably reflect the situation in the mucosa. Das and colleagues have described a colon bound colitis associated autoantibody (CCA) which is claimed to be highly specific for ulcerative colitis and extractable from almost all colons showing total active disease..$^{7-9}$ The corresponding antigen has been characterised as a $40 \mathrm{kDa}$ epithelial membrane protein which is expressed by colon, gall bladder, and skin, ${ }^{10}$ possibly providing an immunological explanation for some of the biliary and cutaneous manifestations of ulcerative colitis." The phenomenon of CCA, however, has yet to be confirmed by independent investigators.

This study was designed to attempt to confirm the existence of CCA, and to assess the prevalence of and relationship between CCA, classical anticolon antibody, and cytotoxic anticolon antibody in patients with ulcerative colitis.

\section{Methods}

Fresh surgical specimens were obtained from 16 patients undergoing colectomy: group A for extensive active ulcerative colitis, and group B for other reasons (Table I). Serosal fat was removed from the specimens, which were then washed and stored at $-70^{\circ} \mathrm{C}$. Serum samples from 29 patients with ulcerative colitis, 12 with Crohn's disease, and 20 healthy control subjects (Table II) were stored at $-20^{\circ} \mathrm{C}$.

\section{CCA EXTRACTION}

The CCA extraction technique followed closely that previously described. ${ }^{89}$ Briefly, each tissue specimen was homogenised in phosphate 
TABLE I Colonic immunoglobulin extracts: patient details

\begin{tabular}{|c|c|c|c|c|}
\hline & Group $A(n=8)$ & & Group $B(n=8)$ & \\
\hline $\begin{array}{l}\text { Age range (years) } \\
\text { Diagnosis }\end{array}$ & $\begin{array}{l}\text { 18-64 } \\
\text { Active total ulcerative colitis } \\
\text { Active subtotal ulcerative colitis }\end{array}$ & $\begin{array}{l}6 \\
2\end{array}$ & $\begin{array}{l}18-67 \\
\text { Active distal ulcerative colitis } \\
\text { Idiopathic constipation } \\
\text { Crohn's colitis } \\
\text { Gardner's syndrome }\end{array}$ & $\begin{array}{l}4^{\star} \\
2 \\
1 \\
1\end{array}$ \\
\hline $\begin{array}{l}\text { Preoperative steroid } \\
\text { treatment }\end{array}$ & 8 & & 5 & \\
\hline
\end{tabular}

${ }^{\star}$ Macroscopically normal bowel proximal to active distal ulcerative colitis in two.

TABLE II Serum samples: patient details

\begin{tabular}{llll}
\hline & $\begin{array}{l}\text { Ulcerative } \\
\text { colitis } \\
(n=29)\end{array}$ & $\begin{array}{l}\text { Crohn's } \\
\text { disease } \\
(n=12)\end{array}$ & $\begin{array}{l}\text { Control } \\
\text { subjects } \\
(n=20)\end{array}$ \\
\hline Interquartile age range (years) & $27-55$ & $26-42$ & $28-55$ \\
Active disease & $17^{\star}$ & 5 & - \\
Inactive disease & $12^{\star}$ & $7^{\star}$ & - \\
Steroid treatment when sampled & 5 & 5 & 0 \\
\hline
\end{tabular}

^One with active ulcerative colitis, seven with inactive ulcerative colitis, and two with inactive Crohn's disease had primary sclerosing cholangitis.

buffered saline containing $2 \mathrm{mM}$ phenylmethylsulphonyl fluoride, filtered through a coarse gauze mesh to remove fibrous debris, and then centrifuged at $2000 \mathrm{rpm}$. The pellet was washed four times with phosphate buffered saline containing phenylmethylsulphonyl fluoride ( $2 \mathrm{mM})$, ethylenediamine tetra-acetate $(2 \mathrm{mM})$, and sodium azide ( $2 \mathrm{mM})$.

Tissue bound immunoglobulin was eluted from the pellet by stirring in $0.02 \mathrm{M}$ citrate buffer (pH 3.2) for two hours. After centrifugation the procedure was repeated with $0.1 \mathrm{M}$ glycine-HCl buffer ( $\mathrm{pH} \mathrm{2.8)}$ for a further two hours. Both eluates were rapidly neutralised and then passed down a Protein A-Sepharose CL4B column to extract the IgG fraction. IgG was eluted from the column using $0 \cdot 1 \mathrm{M}$ glycine- $\mathrm{HCl}$

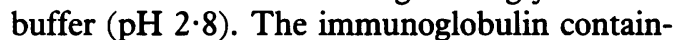
ing extract (4-21 ml) was neutralised and stored at $-20^{\circ} \mathrm{C}$ awaiting analysis.

\section{IgG ELISA}

Immunoglobulin $\mathrm{G}$ concentrations were determined with an enzyme linked immunosorbent assay (ELISA) technique. Briefly, rabbit antihuman IgG (Dakopatts) was diluted to $1 \mu \mathrm{g} / \mathrm{ml}$ in $0.1 \mathrm{M}$ bicarbonate buffer ( $\mathrm{pH} \mathrm{9.5)} \mathrm{and}$ incubated in the wells of a Linbro EIA II Plus 96 well ELISA plate. The wells were blocked with $10 \%$ fetal calf serum, and samples and standards were then added in quadruplicate. The ELISA was completed by adding 1/1000 peroxidaselabelled rabbit antihuman immunoglobulin (Dakopatts) for one hour, developing with OPD/ hydrogen peroxide and determining optical density at $492 \mathrm{~nm}$.

The ELISA saturated at an IgG concentration of about $200 \mathrm{ng} / \mathrm{ml}$. The mean coefficient of variation for the standards in a typical experiment was $2 \cdot 8 \%$.

\section{ANTIBODY-DEPENDENT CYTOTOXICITY ASSAY}

Cells of the colon cancer cell line HT29, maintained in a relatively differentiated state by culture in glucose free medium, were used as target cells in the cytotoxicity assay. Viable
Figure 2: Gross IgG yields per unit wet weight of colon for group $A$ (extensive active ulcerative colitis) and group $B$ (disease control subjects).

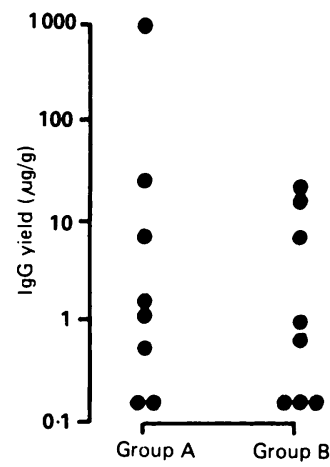

HT29 cells were washed and suspended in Leibovitz (L-15) medium with glutamine (Gibco) containing $10 \%$ fetal calf serum. One million cells (in $0.5 \mathrm{ml}$ ) were incubated for 60 minutes at $37^{\circ} \mathrm{C}$ with $100 \mu \mathrm{Ci}$ chromium-51 as sodium chromate (Amersham International).

After washing, 5000 cells (in $0.1 \mathrm{ml}$ ) were introduced into each well of a 96 well cell culture plate. Medium alone was put in the edge wells to avoid an 'edge effect.' After overnight incubation at $37^{\circ} \mathrm{C}$ and then washing, $60 \mu \mathrm{l}$ of $\mathrm{L}-15+$ $10 \%$ fetal calf serum and $40 \mu \mathrm{l}$ of neat test serum or extract in quintuplicate were added to the wells. The plate was incubated for 60 minutes at $37^{\circ} \mathrm{C}$ before the addition of effector cells.

Peripheral blood mononuclear cells were obtained from a single healthy subject by centrifuging fresh venous blood through FicollHypaque Mono/Poly Resolving Medium(Flow). The cells were washed three times and resuspended in L- $15+10 \%$ fetal calf serum: $4 \times 10^{5}$ effector cells (in $200 \mu \mathrm{l}$ ) were added to each well to achieve an effector:target cell ratio of $80: 1$, shown by preliminary studies to be optimal.

After four hours' incubation at $37^{\circ} \mathrm{C} 150 \mu \mathrm{l}$ aliquots were aspirated from each well and $\gamma$ emission above background (A) determined. Further $150 \mu \mathrm{l}$ aliquots were aspirated and counted (B) after incubation overnight with 150 $\mu l$ 5\% Triton X100. For each well, experimental percentage lysis $(E)$ and specific percentage lysis (S) were determined as follows:

$$
E=\frac{100 \times A}{(A / 2)+B} \quad S=\frac{100 \times\left(E-E_{0}\right)}{100-E_{o}}
$$

$\left(E_{o}\right.$ is the value of $E$ in the absence of serum (that is, spontaneous lysis).)

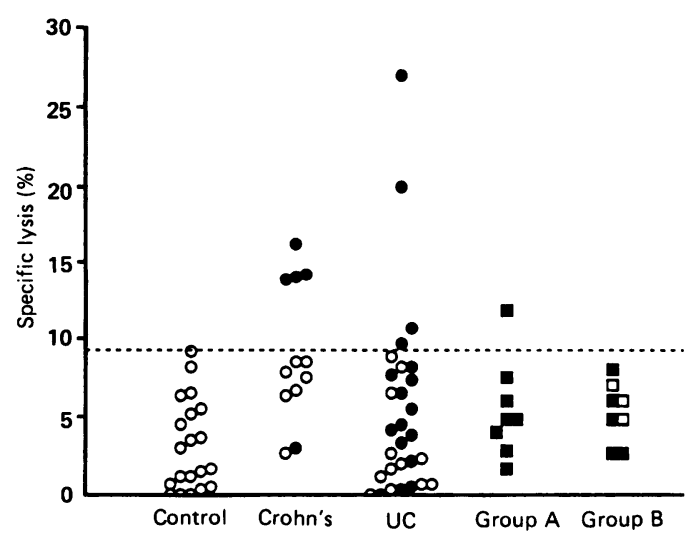

Figure 3: Specific percentage lysis in the cytotoxicity assay for sera (circles) and colonic immunoglobulin extracts (squares). Closed symbols indicate patients with active inflammatory bowel disease. $U C=$ ulcerative colitis. 
TABLE III Summary of the distribution of positive immunohistochemistry and cytotoxicity results

\begin{tabular}{|c|c|c|c|c|c|}
\hline & \multirow{2}{*}{\multicolumn{2}{|c|}{ Colonic IgG extracts }} & \multicolumn{2}{|l|}{ Sera } & \multirow[b]{3}{*}{ Associations } \\
\hline & & & \multirow{2}{*}{$\begin{array}{l}\text { Ulcerative } \\
\text { colitis }\end{array}$} & \multirow{2}{*}{$\begin{array}{l}\text { Crohn's } \\
\text { disease }\end{array}$} & \\
\hline & Group A & Group B & & & \\
\hline 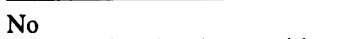 & 8 & 8 & 29 & 12 & \\
\hline Immunohistochemistry positive & 0 & 0 & 13 & 4 & $\begin{array}{l}\text { Primary sclerosing } \\
\text { cholangitis }\end{array}$ \\
\hline Cytotoxicity positive & 0 & 0 & 4 & 4 & Active disease \\
\hline
\end{tabular}

\section{IMMUNOHISTOCHEMISTRY}

Evidence of affinity of serum and colonic immunoglobulin extracts for colonic epithelium and liver was sought using $4 \mu \mathrm{m}$ ethanol-fixed frozen sections of histologically normal tissue and a standard two stage immunoperoxidase technique. In an attempt to enhance the amplification of the immunoperoxidase system, the immunohistochemical studies were repeated using a standard avidin-biotin complex (ABC) technique (Dakopatts).

STATISTICAL ANALYSIS

The results were analysed using the $\chi^{2}$ test (with Yates's correction) and the Mann-Whitney U test for non-parametric data.

\section{Results}

IMMUNOGLOBULIN YIELD

The IgG yields in the colonic extracts ranged from less than $0 \cdot 1 \mu \mathrm{g} / \mathrm{g}$ to almost $1 \mathrm{mg} / \mathrm{g}$ wet weight, with a skewed distribution (Fig 2). There was no significant difference between the two patient groups.

\section{CYTOTOXICITY ASSAY}

Preincubation viability of both target and effector cell populations exceeded $95 \%$. Mean spontaneous lysis was $\mathbf{9 \cdot 7 \%}$. The intra-assay coefficient of variation for experimental lysis in a typical batch was $15 \cdot 4 \%$. Estimated interassay coefficient of variation for experimental lysis was $48 \cdot 3 \%$.

Lysis was above the normal range (control mean ( +2 SD) $9 \cdot 3 \%$ ) for eight $(20 \%)$ of the sera from patients with inflammatory bowel disease overall, and this subgroup included patients both with ulcerative colitis and Crohn's disease (Fig 3). All eight sera exhibiting enhanced specific lysis were from patients with active disease $\left(\chi^{2}=6.42 ; p<0.025\right)$, giving an overall prevalence of $36 \%$ in the active disease subgroup. In the subgroup with active ulcerative colitis, four of eight with extensive disease and none of nine with distal disease had supranormal specific lysis. None of the nine sera from patients with primary sclerosing cholangitis and inactive bowel disease had enhanced specific lysis.

The cytotoxicity assay failed to provide evidence of antibody with affinity for HT29 cells in the tissue immunoglobulin extracts examined, and almost all values fell within the serological normal range. There was no significant difference in specific lysis values for group $A$ and group B (Fig 3).
IMMUNOHISTOCHEMISTRY

Classical anticolon antibody (Fig 1) was present in $17(41 \%)$ of the sera from patients with inflammatory bowel disease and in none of the sera from control subjects $\left(\chi^{2}=9.53 ; p<0.005\right)$. There was no significant difference between ulcerative colitis and Crohn's disease or between active and inactive inflammatory bowel disease in the prevalence of detectable antibody. Six of the 10 sera from patients with primary sclerosing cholangitis were antibody positive.

Immunohistochemical studies with the colonic immunoglobulin extracts using two-stage immunoperoxidase and $\mathrm{ABC}$ techniques failed to provide any evidence of antibody with affinity for colonic epithelium, intrahepatic biliary epithelium, or liver parenchyma.

\section{CORRELATION BETWEEN ANTIBODY ACTIVITIES}

There was no correlation between the presence of classical and cytotoxic anticolon antibody in the sera from patients with inflammatory bowel disease. Overall, $56 \%$ of patients were positive in one or both assays; the prevalence rose to $73 \%$ for those with active disease. The results are summarised in Table III.

\section{Discussion}

This study confirms the previously reported characteristics of classical anticolon antibody in inflammatory bowel disease. ${ }^{1-3}$ The lack of association with disease extent and activity, absence from the sera of most patients with the disease, and evident lack of cytotoxic activity all strongly suggest that this antibody is merely an epiphenomenon. The suggestion of an increased prevalence of the classical antibody in patients with primary sclerosing cholangitis is also confirmed ${ }^{3}$; this largely accounts for the higher overall prevalence of the antibody found in this study than reported elsewhere.

The killer cell assay is a highly sensitive technique for detecting cell bound IgG. ${ }^{12}$ The technique, however, is critically dependent on the prevailing conditions, reflected by the high interassay coefficient of variation in this study. HT29 cells were used as targets in preference to extracted colonic epithelial cells because of the potential problems with standardisation and the high spontaneous death rate associated with the latter. HT29 cells are relatively well differentiated and show a number of the characteristics of normal colonic epithelium such as polarity and 'tight junctions', ${ }^{13}$ but the assumption must be made that they express all relevant antigens expressed by colonic epithelial cells.

In four published studies the capacity of serum from patients with inflammatory bowel disease to mediate antibody dependent cytotoxicity for colonic epithelial cells has been assessed. ${ }^{414}$ The experimental details have varied, and the design or analysis, or both, are open to criticism, making direct comparison with the results of the present study difficult. Nevertheless, all studies agree that sera from a proportion of patients with inflammatory bowel disease have the capacity to mediate antibody dependent cytotoxicity for colonic epithelial 
cells, and all but one suggest an association with disease activity.

A major flaw in the hypothesis that cytotoxic autoantibody is involved in the pathogenesis of ulcerative colitis is the failure to detect antibody in the serum of all patients with active disease. It is, however, invalid to assume that the absence of antibody from the serum indicates absence of antibody from the diseased mucosa: it is clearly tissue rather than serum autoantibody activity that is of potential importance in pathogenesis. It was therefore important to attempt to confirm the suggestion by Das and colleagues that a highly specific tissue-bound autoantibody is extractable from colons with active ulcerative colitis. $^{7-9}$ The mean immunoglobulin yields in this study compare well with those of Takahashi and Das: $121 v 74 \mu \mathrm{g} / \mathrm{g}$ respectively for extensive active ulcerative colitis and $6 v 11 \mu \mathrm{g} / \mathrm{g}$ for control subjects. The distribution, however, is wide and highly skewed in both studies: parametric analysis is therefore inappropriate.

CCA has been claimed to produce positive immunofluorescence on colonic sections, ${ }^{7}$ and the killer cell assay is an exquisitely sensitive method of detecting cell bound IgG. ${ }^{12}$ The uniform failure of both immunohistochemical and cytotoxic techniques to show colonic epithelial cell autoantibody in the extracts is therefore disappointing and strongly suggests that the extracts do not contain autoantibody.

The absence of CCA activity in the colonic extracts does not entirely exclude a role for anticolonic epithelial cell antibody in the pathogenesis of ulcerative colitis. It may be, for example, that levels of epithelial bound autoantibody are below the limits of detection due to restricted access or rapid turnover. Such a situation is suggested by the failure to show tissuebound classical anticolon antibody immunohistochemically in patients known to be antibody positive, unless the tissue sections are first incubated with autologous serum in vitro. ${ }^{2}$ Showing the absence of cytotoxic antibody in colonic extracts from patients known to have circulating cytotoxic antibody would provide additional evidence. Unfortunately, none of the three colectomy patients in Group A in this study for whom serum was available were cytotoxic antibody positive.

In the absence of CCA, what is the nature of the immunoglobulin extracted from the colon specimens? The extraction technique does not distinguish between membrane-associated antigen-bound and Fc-bound immunoglobulin. In view of the many mucosal inflammatory cells which express Fc receptors it seems likely that the bulk of the extracted material is antigen nonspecific, Fc-bound immunoglobulin.

This study has shown that the antiepithelial autoantibody response in ulcerative colitis is heterogeneous and non-uniform: classical and cytotoxic anticolon antibodies are distinct entities with characteristic features. There was no evidence that a specific, extractable, epithelialbound autoantibody is commonly present in active ulcerative colitis. The pathogenetic importance of anticolon epithelial antibodies in ulcerative colitis remains speculative.

JAS was in receipt of a Pharmacia junior research fellowship.

1 Broberger O, Perlmann P. In vitro studies of ulcerative colitis I. Reactions of patients serum with human foetal colon cells in tissue cultures. F Exp Med 1963; 117: 705-15.

2 Wright R, Truelove SC. Autoimmune reactions in ulcerative colitis. Gut 1966; 7: 32-40.

3 Chapman RW, Cottone M, Selby WS, Shepherd HA, Sherlock S, Jewell DP. Serum autoantibodies, ulcerative colitis and primary sclerosing cholangitis. Gut 1986; 27: 86coli.

4 Shorter RG, Huizenga KA, ReMine SG, Spencer RJ. Effects of preliminary incubation of lymphocytes with serum on their cytotoxicity for colonic epithelial cells. Gastroenterolog 1970; 58: 843-50

5 Das KM, Kadono Y, Fleischner GM. Antibody-dependen cell-mediated cytotoxicity in serum samples from patient with ulcerative colitis. Am $\mathcal{F}$ Med 1984; 77: 791-6.

6 Auer IO, Grosch L, Hardorfer C, Roder A. Ulcerative colitis specific cytotoxic IgG-autoantibodies against colonic epithelial cancer cells. Gut 1988; 29: 1639-47.

7 Das KM, Dubin R, Nagai T. Isolation and characterization of colon tissue-bound antibodies from patients with idiopathic ulcerative colitis. Proc Natl Acad Sci 1978; 75: 4528-32.

8 Nagai T, Das KM. Detection of colonic antigen in tissues from ulcerative colitis using purified colitis colon tissue-bound ulcerative colitis using purified colitis
IgG. Gastroenterology 1981; 81: 463-70.

9 Takahashi F, Das KM. Isolation and characterization of a colonic autoantigen specifically recognized by colon tissuebound immunoglobulin $\mathrm{G}$ from idiopathic ulcerative colitis f Clin Invest 1985; 76: 311-8.

10 Vecchi M, Sakamaki S, Das KM. The Mr 40,000 coloni protein, an autoantigen associated with ulcerative colitis recognition of a similar epitope in skin and biliary tree by anti-Mr 40,000 antibodies [Abstract]. Gastroenterology 1987; 92: A1682.

11 Das KM, Jeffers L, Squillante L, Hyder S, Reddy R, Schiff E The presence of circulating antibodies in patients with The presence of circulating antibodies in patients with
sclerosing cholangitis against an epitope on $\mathrm{Mr} 40,000$ sclerosing cholangitis against an epitope on $\mathrm{Mr} 40,000$ protein shared by colon and bile duct

12 Lovchik JC, Hong R. Antibody-dependent cell-mediated cytotoxicity (ADCC): analyses and projections. Prog Allergy 1977; 22: 1-44.

13 Trugnan G, Rousset M, Chantret I, Barbat A, Zweibaum A The post-translational processing of sucrase-isomaltase in HT29 cells is a function of their state of enterocytic differentiation. $\mathcal{F}$ Cell Biol 1987; 104: 1199-205.

14 Kemler BJ, Alpert E. Inflammatory bowel disease: study of cell mediated cytotoxicity for isolated human colonic epithelial cells. Gut 1980; 21: 353-9. 